\title{
A Study on Reinke's Edema Treated by Surgery
}

\author{
Takashi Taniyama $^{1)}$, Tomonori Sugiyama ${ }^{2)}$, Mamika Araki²), Kouhei Fukukita ${ }^{2)}$, \\ Hiroyuki Yamada ${ }^{2)}$, Yoshio Hatakeyama ${ }^{1)}$, Shinji Koyama ${ }^{1)}$ and Hiroshi Hosoi ${ }^{3)}$
}

Between 2005 and 2010, we treated 30 cases of Reinke's edema by surgery. The subjects were 9 men and 21 women aged 33 to 83 years (mean: 57.5 years). Besides the 5 patients whose smoking history was not clear, 22 patients (88\%) were smokers and 3 patients (12\%) were non-smokers. Among the 20 patients who answered a questionnaire, the voice condition finally improved in 13 patients (65\%), while it improved by 1 week after the surgery in 5 patients $(25 \%)$. In cases of Reinke's edema, we must be careful in making the right choice of operation, and in addition to perfoming careful operation, must also try to motivate the patients for smoking cessation.

Keywords : Reinke's edema, smoking, smoking cessation

\section{References}

1）田村悦代：声帯ポリープ，ポリープ様声帯. 耳鼻・頭頸外 科 77: 709-713, 2005 .

2）米川紘子, 太田文彦, 小池靖夫 : ポリープ様声帯の臨床. 日気管食道会報 34：409-417, 1983 .

3）河瀬典子, 澤島政行, 広瀬 肇, 他 : 声帯結節，声帯ポリー プ，ポリープ様声帯に関する統計的観察一年齢分布，既往 歴，生活歴を中心として。耳鼻咽喉 54：683-688, 1982.

4) 中井百香, 牧山 清, 中井孝尚, 他 : ポリープ様声帯の臨 床像と手術治療後の経過について. 日気管食道会報 58: 816, 2007.

5）正来 隆, 堀口利之, 牧野寛之, 他：ポリープ様声帯 145 例の検討（1995 年〜 2007 年). 日気管食道会報 59: 519$523,2008$.

6) Matuso K, Hirano M, Kasuya T, et al. : Polypoid vocal fold-a review of 97 cases—. Pract Otol (Kyoto) 73: 1187-1198, 1980.

7）島谷陽一, 永井みどり, 中島 格, 他：喉頭のポリープ様 病変と喫煙.耳鼻と臨 25: 448-452, 1979.

8）鉁原東紅, 井上健造, 溝尻源太郎, 他 : ポリープ様声帯の 疫学と病理. 耳鼻と臨 39 補 1: 297-302, 1993.

9）尾形キョウ子：ポリープ様声帯の臨床的研究. 日気管食道
会報 25：22-31, 1974.

10) Ohno T, Takegoshi H and Kikuchi S : A case of tracheotomy necessitated for a giant polypoid vocal fold. Pract Otol (Kyoto) 97: 255-258, 2004.

11) Yonekawa $\mathrm{H}$ : A clinical study of Reinke's edema. Auris Nasus Larynx 15: 57-78, 1988.

12) Krecicki T, Zalesska-Krecicka M, Pastuszek P, et al. : Treatment of Reinke's edema among different professional groups: presentation of results. Int J Occup Med Environ Health 17: 279-284, 2004.

13) Nielsen VM, Højslet PE and Karlsmose M : Surgical treatment of Reinke's oedema (long term results). J Laryngol Otol 100: 187-190, 1986.

14）野崎智嗣, 溝尻源太郎, 柴 裕子, 他 : ポリープ様声帯, 声帯ポリープ, 声帯結節に対する手術の効果 : 術前後の音 声機能の比較による研究. 音声言語医 42: 24-32, 2001.

15）柴 裕子, 溝尻源太郎, 野崎智嗣 : ポリープ様声帯の発声 機能一病型分類と手術の役割. 日耳鼻会報 95：1345-1351, 1992.

16）森川郁郎, 深浦順一, 渡邊 宏, 他 : ポリープ様声帯の手 術療法一術後音声早期改善例と非改善例との比較一. 耳鼻 と臨 39 補 1: 291-296, 1993.
1) Department of Otorhinolaryngology, Yamatotakada Municipal Hospital

2) Department of Head and Neck Otorhinolaryngology, Ise Red Cross Hospital

3) Department of Otorhinolaryngology Head and Neck Surgery, Nara Medical University
Corresponding Author Address : Takashi Taniyama

ta-taniyama@dolphin.ocn.ne.jp 


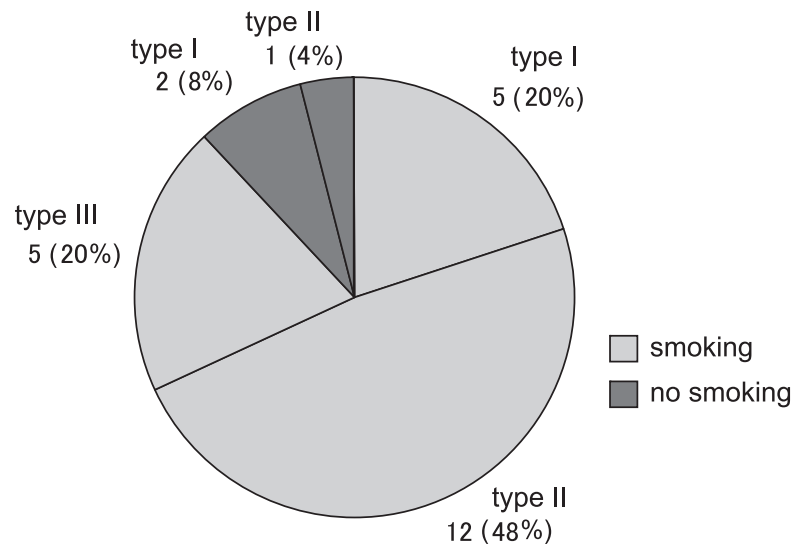

Percentage of smoking habit and classification of vocal cord findings.

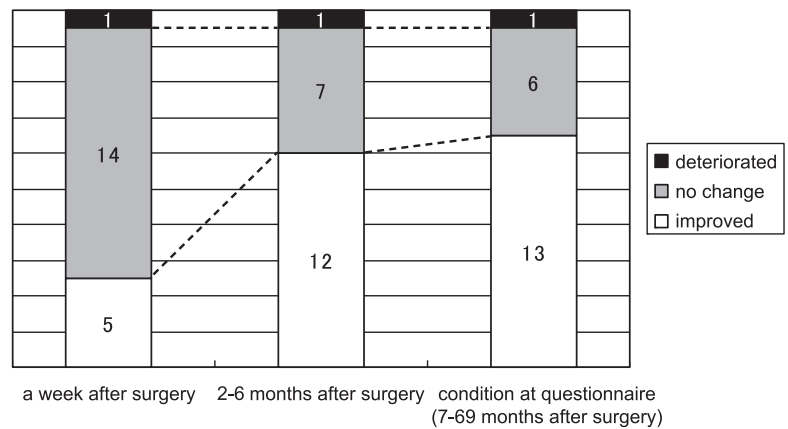

Subjective changes in postoperative phonation over time. 